\title{
REAL OPTIONS IN THE INFORMATION SYSTEM DESIGN
}

\author{
Р.В. Соколов \\ РЕАЛЬНЫЕ ОПЦИОНЫ В УПРАВЛЕНИИ ПРОЕКТИРОВАНИЕМ \\ ИНФОРМАЦИОННЫХ СИСТЕМ
}

The article reviews the prerequisites to use real options in the design of information systems (IS) as a variety of investment designing. On the one hand, these presuppositions include the risk and uncertainty in the long process of designing and, on the other hand, the possibility to demonstrate the managerial flexibility of the project manager. The main factors of uncertainty and risk include the functionality of IS, requirements to which are approximately formulated by the customer, and then are necessary to be clarified at every stage of the design in accordance with the changing circumstances and the project financing possibilities. The assessment methods of real options such as the Black-Scholes model, binary tree, etc. require initial data that are difficult and even impossible to obtain while designing enterprise information system due to the insufficiency of statistics that characterize the cash flows of such projects. Furthermore, these models ignore the features of the IS design that could be reflected in an optional approach to design. The features of the optional approach to IS design are analyzed and summarized in four groups: 1) factors of uncertainty and risk; 2) the variant approach to design; 3) staging of the design process; 4) the iterative nature of the design process. The classification of types of real options in the design process is proposed. The factors of management flexibility by design stages and types of real options are analyzed. The work offers a consistent economic efficiency assessment of IS based on the expected values of the expanded net present value of the project that are confirmed at every stage of the design. The formula of the expected value of the cost of a real option for binary development of the design process is proposed. The use of real options in the information system design, taking into account the peculiarities of this process, makes it possible to improve the economic efficiency of the project and its attractiveness.

REAL OPTIONS; INFORMATION SYSTEM DESIGN PROCESS; MANAGEMENT FLEXIBILITY; OPTIONAL APPROACH FEATURES; EXPANDED NET PRESENT VALUE; TYPES OF REAL OPTIONS; THE DESIGN STAGES; CONSISTENT EFFICIENCY ASSESSMENT.

Рассматриваются предпосылки целесообразности использования реальных опционов в управлении проектированием информационных систем (ИС) как разновидности инвестиционного проектирования. К этим предпосылкам относятся, с одной стороны, наличие факторов риска и неопределенности в длительном процессе проектирования, с другой - возможности проявления управленческой гибкости менеджером проекта. В качестве основных факторов неопределенности и риска рассматриваются функциональность ИС, требования к которой первоначально заказчиком формулируется достаточно приблизительно и подлежат обоснованному уточнению на всех стадиях проектирования в соответствии с изменяющимися обстоятельствами, а также возможности финансирования проекта. Методы оценки реальных опционов, такие как модель Блэка-Шольца, бинарного дерева и др., требуют использования исходных данных, которые трудно, а в ряде случаев невозможно получить в процессе проектирования ИС промышленных предприятий из-за недостаточности статистических данных, характеризующих денежные потоки данных проектов. К тому же эти модели не учитывают особенности проектирования ИС, которые могут быть отражены в опционном подходе к проектированию. Анализируются особенности опционного подхода в проектировании ИС, сведенные в четыре группы: 1) наличие факторов неопределенности и риска, характерных для проектирования ИС; 2) вариантный подход в проектировании; 3) стадийность процесса проектирования ИС; 4) итерационный характер процесса проектирования ИС. Предлагается классификация видов реальных опционов в процессе проектирования. Анализируются факторы управленческой гибкости по стадиям проектирования и видам реальных опционов. Предлагается последовательная оценка экономической эффективности ИС на основе ожидаемых значений расширенной чистой приведённой стоимости проекта, уточняемых при переходе от одной стадии к другой. Предлагается формула ожидаемого значения стоимости реального опциона для бинарного развития процесса проектирования. Применение реальных опционов в процессе проектирования ИС с учетом особенностей этого процесса позволяет повысить оценку экономической эффективности проекта и его привлекательность.

РЕАЛЬНЫЕ ОПЦИОНЫ; ПРОЕКТИРОВАНИЕ ИНФОРМАЦИОННЫХ СИСТЕМ; УПРАВЛЕНЧЕСКАЯ ГИБКОСТЬ; ОСОБЕННОСТИ ОПЦИОННОГО ПОДХОДА; РАСШИРЕННАЯ ЧИСТАЯ ПРИВЕДЕННАЯ СТОИМОСТЬ; ВИДЫ РЕАЛЬНЫХ ОПЦИОНОВ; СТАДИИ ПРОЕКТИРОВАНИЯ; ПОСЛЕДОВАТЕЛЬНАЯ ОЦЕНКА ЭФФЕКТИВНОСТИ. 
Introduction. Improving the economic flexibility of the investment projects, which are characterized by a high risk and uncertainty degree, requires a flexible management of the design process, considering the changing conditions. This accounts for the interest to use real options in the investment projects based on the managerial flexibility $[1,14,16]$.

Enterprise information system projects represent a variety of investment projects, which are characterized by a volatility in external and internal environment. Therefore, they require the managerial flexibility in a long design process $[2,3]$. According to the results of the research [10,11], only $26 \%$ of investment projects completed successfully in industrialized countries. Moreover, $46 \%$ of them did not produce tangible results and $28 \%$ discontinued. This data show a lack of accuracy of currently used methods of the economic efficiency assessment of investment projects.

The use of real options in investment projects allows increasing the assessment of their expected economic efficiency. If Net Present Value (NPV) is used as a conventional indicator of the economic efficiency of an investment project [5], this indicator could be increased to the value of the expended Net Present Value (eNPV) taking into account the value of the option $[1,15]$. Thus,

$$
\mathrm{eNPV}=\mathrm{NPV}+\mathrm{ROV},
$$

where ROV - Real Option Value.

There are several papers concerning the use of the real options in investment projects, including papers of Limitovskiy M.A. [1], Ilyin I.V. [2], etc.

Methods and models of economic efficiency assessment of real options such as the BlackScholes model, binary tree and others became well-known [1, 2, 8, 9]. However, these models and methods require using raw data, which are difficult, and in some cases impossible to get while designing enterprise information system of enterprises. It happens due to the insufficiency of statistics that characterizes the cash flows of such projects. In addition, these models and methods do not take into account the features of the information systems design, which can be reflected in the optional approach to design.

Problem statement. The use of real options in the information system design could be based on drawing a decision tree taking into account the peculiarities of the design process.
The task solution requires:

- establishing the main features of the information system design process that makes it possible to use the real options;

- offering a quantitative assessment of the expected value of a real option;

- setting the order of the economic efficiency assessment of the information system based on expected values of the expended Net Present Value by design stages;

- clarifying the classification of the real options in the information system design process;

- matching the factors of the managerial flexibility and the types of the real options by the design process stages.

Research technique. The main features to use the optional approach to the information system design are:

1. The presence of uncertainty and risk peculiar to information system design.

These factors are reflected in the contradictory values of generalized indicators of the information system project constituting the so-called compromise quads [3]:

- The information system functionality;

- The development cost;

- The development duration;

- The design documentation quality.

The opportunity to change the course of the project provides the project manager with the basis of insurance risks of investing in the project. The analysis of project risks and the possibility to reduce them by means of the managerial flexibility are provided by the wellknown methods of the information system efficiency assessment TEI (Total Economic Impact) in addition to the comparison of costs and benefits [12].

2. The variant approach to the design.

The managerial flexibility should be visible in the organization and planning a multivariable design process, and not an exclusive variant of the information system development. It raises the possibility to choose the most effective design solutions [3]. The variant approach provides the the basis for applying real options in the information system design.

Let us estimate the value of eNPV and ROV in case of a two-variant approach to the solution made by the project manager based on the value of the NPV. The Fig. 1 shows the decision tree in a two-variant design. 


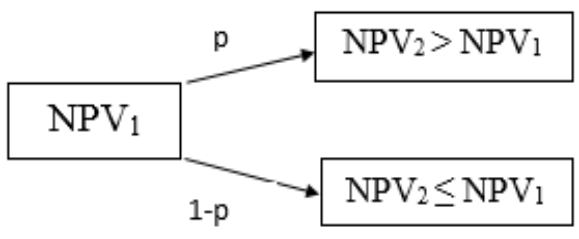

Fig. 1 The decision tree in a two-variant design.

Fig. 1 shows the following notations:

$\mathrm{NPV}_{1}$ - the expected value of the Net Present Value of the information system project for the first variant of its implementation;

$\mathrm{NPV}_{2}$ - the expected value of the Net Present Value of the information system project for the second variant of its implementation;

$\mathrm{p}$ - the expert probability that the value of $\mathrm{NPV}_{2}$ would be higher if the second variant is chosen; event.

$1-p-$ the expert probability of the opposing

Obviously, the project manager will approve the second option, if it does not contradict the valid investment and other restrictions.

In accordance with the basic principles of the approach to real options [13] the project manager has the ability, but not the obligation, to choose the second variant, because he knows the value of the NPV of the second variant. Obviously, the second option would not be selected in case when NPV2 $\leq$ NPV1, and the project manager would choose the first variant.

The expected value of eNPV according to the optional approach would be

$$
\mathrm{eNPV}=\mathrm{pNPV}_{2}+(1-\mathrm{p}) \mathrm{NPV}_{1}-\mathrm{k}_{\text {пр }},
$$

where $\mathrm{k}_{\text {пр }}$ - extra development costs of the second variant of project.

That is why

$$
\mathrm{eNPV}=\mathrm{NPV}_{1}+\mathrm{p}\left(\mathrm{NPV}_{2}-\mathrm{NPV}_{1}\right)-\mathrm{k}_{\text {пр }} \text {, }
$$

The expected value of ROV is

$$
\mathrm{ROV}=\mathrm{eNPV}-\mathrm{NPV}_{1} .
$$

That is why

$$
\mathrm{ROV}=\mathrm{p}\left(\mathrm{NPV}_{2}-\mathrm{NPV}_{1}\right)-\mathrm{k}_{\text {пр }} .
$$

From (5) it follows that the higher the expert probability of improvement of NPV for the second variant of the project is and the higher the expected increment of the NPV, when the second variant is chosen, the greater the value of ROV will be.
From (5) it also follows, that the expected result of re-design should surpass its cost to make positive the value of a real option.

A variant approach relates primarily to the functionality of the information systems and the implementation of the principle of the new challenges that identify the relevant issues of enterprise management and key success factors of informatization.

A variant approach also applies to the choice of organizational design technologies, information and software of the technical means, the order of the implementation of information system subsystems [3, 6]. This selection is carried out with a focus on the possibility to finance the project, required development time and required quality of design documentation. Fig 2 shows the classification and the composition of the possible real options in the information system design.

Fig. 2 shows options CALL that provide investment in the project, except for the option to withdraw from the project (option PUT).

3 . Stages of the process of the information system design.

With regard to the information system development, the sequence of the design process consists of the following steps:

- The preparatory stage to form an application for design;

- The predesign stage;

- The technical design stage;

- The detailed design stage;

- The commissioning stage;

- The support step.

The transition from one stage of design to other one is accompanied by more managerial decision-making information for the project manager and the ability to refine the economic efficiency assessment of the information system.

Table presents the main factors of the managerial flexibility in the design process in relation to the types of real options and the economic efficiency assessment.

As we see in Table, the flexibility of management decisions can occur at all stages of the design process and it covers management decisions to extend or reduce functionality and scalability of the information system, as well as the deferral of the initial design and adjustment of the length of its separate stages. Furthermore, leaving the project is possible if during the development process the project is found ineffective. 


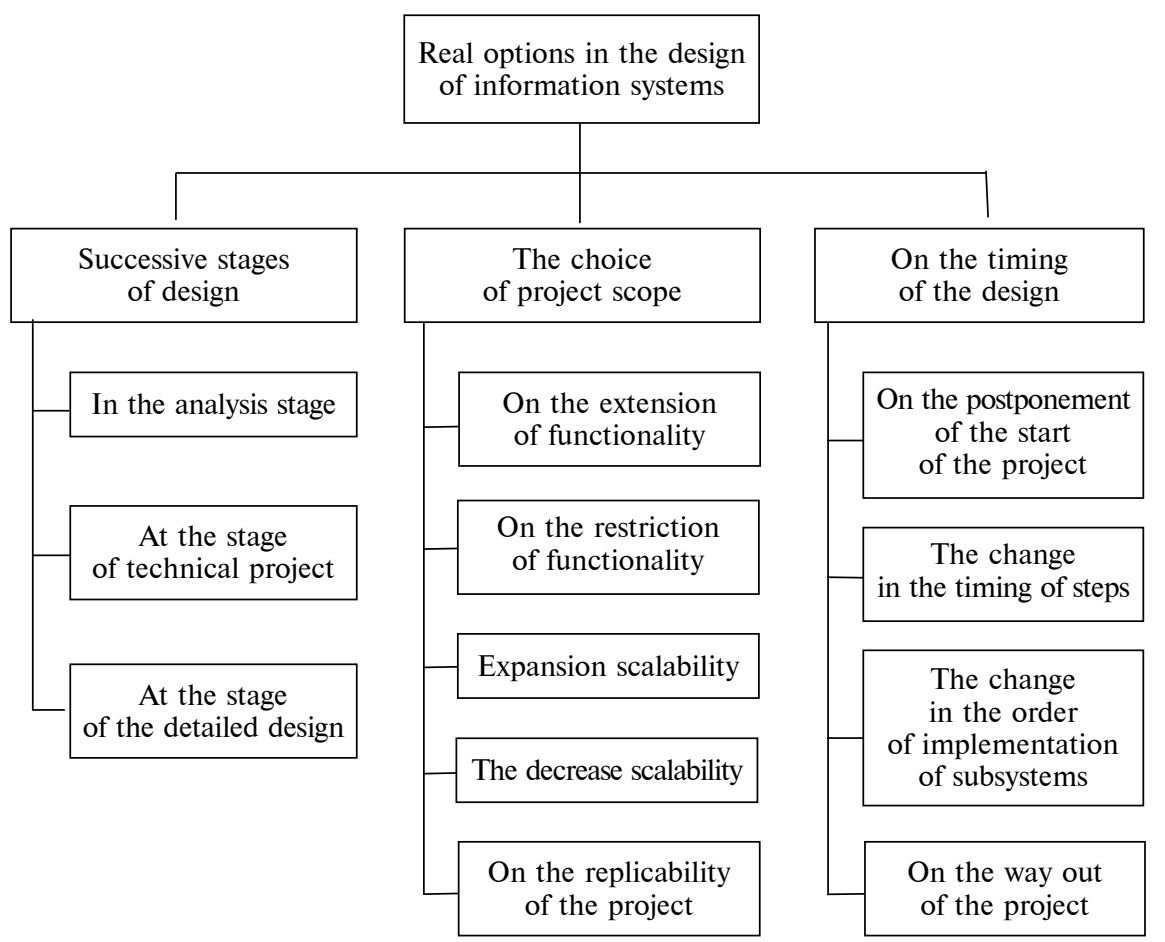

Fig. 2. The classification of the real options in the information system design

The main factors of the managerial flexibility in the design process

\begin{tabular}{|c|c|c|c|}
\hline The design stage & Types of real options & $\begin{array}{l}\text { The main factors of the managerial } \\
\text { flexibility in the design process }\end{array}$ & $\begin{array}{c}\text { The economic } \\
\text { assessment efficiency } \\
\text { of the information system }\end{array}$ \\
\hline $\begin{array}{l}\text { 1. The formation of the } \\
\text { design assignment }\end{array}$ & - & - & $\begin{array}{l}\text { Preliminary assessment } \\
\text { of the expected cost- } \\
\text { effectiveness }\end{array}$ \\
\hline $\begin{array}{l}\text { 2. Analysis: techno- } \\
\text { economic assessment } \\
\text { of the project and } \\
\text { requirement specification } \\
\text { development }\end{array}$ & $\begin{array}{l}\text { To expand or contract } \\
\text { functionality. To withdraw } \\
\text { from the project }\end{array}$ & $\begin{array}{l}\text { Simulation and study of information } \\
\text { system functionality, the choice of } \\
\text { design technology, the account features } \\
\text { of the project financing }\end{array}$ & $\begin{array}{l}\text { The oriented assessment } \\
\text { of the expected cost- } \\
\text { effectiveness }\end{array}$ \\
\hline 3. Technical project & $\begin{array}{l}\text { To expand or contract } \\
\text { functionality. To extend or } \\
\text { contract the scalability. To } \\
\text { change the timing of steps. } \\
\text { To withdraw from the project }\end{array}$ & $\begin{array}{l}\text { The selection and development of } \\
\text { algorithms of functional tasks, a database } \\
\text { structure, an organizational structure, } \\
\text { management, technical support options. } \\
\text { The clarification of the composition } \\
\text { and number of workstations }\end{array}$ & $\begin{array}{l}\text { The updated estimation } \\
\text { of the expected cost- } \\
\text { effectiveness }\end{array}$ \\
\hline 4. Detailed design & $\begin{array}{l}\text { To expand or contract } \\
\text { functionality. To change the } \\
\text { timing of steps. To withdraw } \\
\text { from the project. To replicate } \\
\text { the project }\end{array}$ & $\begin{array}{l}\text { Software selecting, changes in the } \\
\text { composition of the working group } \\
\text { and deadlines. The verification of the } \\
\text { order of the implementation of the } \\
\text { information system subsystems. Accounting } \\
\text { for the functioning capacity of the project }\end{array}$ & $\begin{array}{l}\text { The final evaluation of } \\
\text { the expected cost- } \\
\text { effectiveness }\end{array}$ \\
\hline 5. Imp & - & - & $\begin{array}{l}\text { The assessment of the } \\
\text { actual economic performance }\end{array}$ \\
\hline
\end{tabular}


If according to GOST [4] the economic assessment efficiency of the information system is carried out only at three stages of the design (the stage of analysis, technical design and implementation), then while using real options the economic efficiency assessment, in our opinion, should cover all stages of design and be gradually updated from one stage to the next. In addition, the expected evaluation of real options, corresponding to the possible managerial flexibility at the last stages, should be provided.

The value of the extended NPV in the i-th stage can be calculated by the formula:

$$
\mathrm{eNPV}_{\mathrm{i}}=\mathrm{NPV}_{\mathrm{i}}+\mathrm{ROV}_{\mathrm{i}},
$$

where $\mathrm{NPV}_{i}$ - the value of the net present value of the information system project, calculated in a conventional manner at the $\mathrm{i}$-th stage of the design without the managerial flexibility in the subsequent design stages; $\mathrm{ROV}_{\mathrm{i}}$ - the expected value of real options that arise at the stages subsequent to the $\mathrm{i}$-th stage.

Both values $\mathrm{NPV}_{\mathrm{i}}$, and $\mathrm{ROV}_{\mathrm{i}}$ are gradually clarified from stage to stage, and the opportunities of management flexibility are reduced.

As the main factors of the managerial flexibility of the project manager, which compensate the uncertainty and risks while designing the IS process, the possibility to change the functionality of IS is considered. The customer formulates the requirements to IS approximately and they need to be clarified at every stage of the design in accordance with the changing circumstances and the project financing possibilities.

4. The iterative nature of the information system design.

The iterative nature of the information system design provides the return from the subsequent stages to previous ones to clarify and improve the original design and management decisions, as well as the clarification of the economic efficiency assessment of the information system. The iterative approach is widely used in the information system design and is provided in such models as the incremental, spiral and evolutional [3].

The iterative nature of the design process expands the opportunities of the project manager in terms of the option approach use.

\section{The obtained results}

1. The analysis of the main features of the design process, which provide the possibility to use real options, is presented. These features include: the presence of uncertainties and risks, a variational approach in the design, the staging of the design process and its iterative nature.

2. The formula to calculate the expected value of a real option for binary development of the design process is proposed.

3. The order of the economic efficiency assessment of the information system based on expected values of the expended Net Present Value, which are clarified when passing from one stage to another, is recommended;

4. The classification of the real options in the information system design process by the design stages, the scale of the project and timing is clarified.

5. The factors of the managerial flexibility and types of the real options by the design process stages are matched.

The direction for future research. Future research should be focused on the analysis of the practice in the application of real options in the information system design process.

Thus, the use of real options in the information system design, taking into account the peculiarities of this process, makes it possible to improve the economic efficiency of the project and its attractiveness.

\section{REFERENCES}

1. Limitovskii M.A. Investitsionnye proekty i real'nye optsiony na razvivaiushchikhsia rynkakh. M.: Iurait, 2011. 486 s. (rus)

2. Il'in I.V., Rostova O.V. Metody i modeli upravleniia investitsiiami. SPb.: Izd-vo Politekhn. un-ta, 2011. 215 s. (rus)

3. Sokolov R.V. Proektirovanie informatsionnykh sistem. SPb.: Izd-vo SPBGIEU, 2012. 336 s. (rus)

4. GOST 34.601-90 Informatsionnaia tekhnologiia Kompleks standartov na avtomatizirovannye sistemy.
Avtomatizirovannye sistemy. Stadii sozdaniia. M.: Izd-vo Standartov, 2003. (rus)

5. Metodicheskie rekomendatsii po otsenke effektivnosti investitsionnykh proektov. M.: Izd-vo Minekonomrazvitiia RF, 2008. (rus)

6. Oleinik P.P. Korporativnye informatsionnye sistemy. SPb.: Piter, 2012. 176 s. (rus)

7. Ilyin I.V., Suomalaynen Y.S. Working out of the technique of the estimation of investment projects on the basis of the method of real options in the 
theory of indistinct sets. St. Petersburg State Polytechnical University Journal. Economics, 2009, no. 6-2(90), pp. 114-119. (rus)

8. Davidovski V. Application of real options theory in evaluation of it projects under conditions of risk. St. Petersburg State Polytechnical University Journal. Economics, 2011, no. 4(127), pp. 228-231. (rus)

9. Rogova E.M., Iarygin A.I. Primenenie novykh metodov otsenki innovatsionnykh proektov: model' vzveshennoi polinomial'noi stoimosti real'nogo optsiona. Innovatsii. 2011. № 27. (rus)

10. Gother. URL: Group://gothergroup.com

11. C News. URL: Analitics://cnews.ru (rus)

12. Krasin V. Kak otsenit' ekonomicheskuiu effektivnost'
IT-proekta. URL: //www.itmag.ru (rus)

13. Kliuchnikov V.O. Real'nye optsiony v proektakh informatsionnykh tekhnologii. Rossiiskoe predprinimatel'stvo. 2011. Vyp. 2(198). № 212. S. 118-121. (rus)

14. Kumar R.L. Managing risks in IT projects: an options perspective. Information\&Management. 2002, vol. 40 , no. 1 , pp. $63-74$.

15. Amram M., Kulatilaka N. Real options. Managing strategic investment in an uncertion world. Harvard Business school, 1999.

16. Vorobyov V.P., Lobas A.S., Pyankova D.O. Evaluation of innovation projects based on real options. St. Petersburg State Polytechnical University Journal. Economics, 2013, no. 6-1(185), pp. 182-186. (rus)

\section{СПИСОК ЛИТЕРАТУРЫ}

1. Лимитовский М.А. Инвестиционные проекты и реальные опционы на развивающихся рынках. М.: Юрайт, 2011. 486 с.

2. Ильин И.В., Ростова О.В. Методы и модели управления инвестициями. СПб.: Изд-во Политехн. ун-та, 2011. 215 с.

3. Соколов Р.В. Проектирование информационных систем. СПб.: Изд-во СПБГИЭУ, 2012. 336 с.

4. ГОСТ 34.601-90 Информационная технология. Комплекс стандартов на автоматизированные системы. Автоматизированные системы. Стадии создания. М.: Изд-во Стандартов, 2003.

5. Методические рекомендации по оценке эффективности инвестиционных проектов. М.: Изд-во Минэкономразвития РФ, 2008.

6. Олейник П.П. Корпоративные информационные системы. СПб.: Питер, 2012. 176 с.

7. Ильин И.В., Суомалайнен Ю.С. Разработка методов оценки инвестиционных проектов на основе метода реальных опционов и теории нечетких множеств // Научно-технические ведомости Санкт-Петербургского государственного политехнического университета. Экономические науки. 2009. № 6-2(90). С. 114-119.

8. Давидовская В.Н. Использование теорий реальных опционов для оценки ИТ проектов в условиях риска // Научно-технические ведомости
Санкт-Петербургского государственного политехнического университета. Экономические науки. 2011. № 4(127). С. 228-231.

9. Рогова Е.М., Ярыгин А.И. Применение новых методов оценки инновационных проектов: модель взвешенной полиномиальной стоимости реального опциона // Инновации. 2011. № 27.

10. Gother. URL: Group://gothergroup.com

11. C News. URL: Analitics://cnews.ru

12. Красин В. Как оценить экономическую эффективность ИТ-проекта. URL: //www.itmag.ru

13. Ключников В.О. Реальные опционы в проектах информационных технологий // Российское предпринимательство. 2011. Вып. 2(198). № 212. C. $118-121$.

14. Kumar R.L. Managing risks in IT projects: an options perspective // Information\&Management. 2002, vol. 40, no. 1, pp. 63-74.

15. Amram M., Kulatilaka N. Real options. Managing strategic investment in an uncertion world. Harvard Business school, 1999.

16. Воробьев В.П., Лобас А.С., Пьянкова Д.О. Оценка инновационных проектов на основе метода реальных опционов // Научно-технические ведомости Санкт-Петербургского государственного политехнического университета. Экономические науки. 2013. Вып. 6-1(185). С. 182-186.

SOKOLOV Roman V. - Saint-Petersburg State University of Economics.

191023. Sadovaya str. 27. St. Petersburg, Russia. E-mail: rvsok@yandex.ru

СОКОЛОВ Роман Владимирович - профессор Санкт-Петербургского государственного экономического университета, доктор экономических наук.

191023, ул. Садовая, д. 21, Санкт-Петербург, Россия. E-mail: rvsok@yandex.ru 